\title{
MODEL SISTEM PENDUKUNG KEPUTUSAN KELOMPOK UNTUK PENILAIAN GANGGUAN DEPRESI, KECEMASAN DAN STRESS BERDASARKAN DASS-42
}

\author{
Sri Kusumadewi*1, Hepi Wahyuningsih ${ }^{2}$ \\ ${ }^{1}$ Teknik Informatika, Universitas Islam Indonesia, ${ }^{2}$ Psikologi, Universitas Islam Indonesia \\ Email: ${ }^{1}$ sri.kusumadewi@uii.ac.id, ${ }^{2}$ hepi.wahyuningsih@uii.ac.id \\ *Penulis Korespondensi
}

(Naskah masuk: 13 September 2018, diterima untuk diterbitkan: 06 Februari 2020)

\begin{abstract}
Abstrak
Depresi, kecemasan dan stress merupakan tiga gangguan yang sering dijumpai di masyarakat. Ketiga gangguan tersebut memiliki gejala yang hampir mirip. Depression, Anxiety and Stress Scales (DASS) merupakan salah satu alat ukur psikologi yang dapat digunakan untuk mengukur tingkat keparahan ketiga gangguan tersebut. DASS dengan jumlah item/gejala sebanyak 42 item dikenal dengan nama DASS-42. Alat ukut ini membedakan dengan jelas item/gejala dari setiap gangguan. Setiap gangguan memiliki item yang mempengaruhi sebanyak 14 item. Ketiga gangguan tersebut memiliki sejumlah gejala yang mirip, bahkan suatu gejala dimungkinkan mempengaruhi dua atau tiga gangguan dengan tingkat pengaruh yang berbeda. Pada penelitian ini dibangun model Sistem Pendukung Keputusan Kelompok (SPKK) yang memungkinkan para psikolog untuk berkolaborasi memberikan preferensi terkait prioritas gangguan yang akan terjadi apabila diketahui item/gejala tertentu menurut DASS-42. Preferensi diberikan dengan format ordered vectors. Preferensi yang telah diberikan oleh setiap psikolog selanjutnya diagregasikan untuk mendapatkan preferensi tunggal. Untuk memudahkan proses agregasi/komposisi dilakukan transformasi preferensi ke relasi preferensi fuzzy. Proses agregasi dilakukan dengan menggunakan operator Ordered Weighted Averaging (OWA). Proses seleksi alternatif terbaik dilakukan menggunakan Quantifier Guided Dominance Degree (QGDD). Hasil pengujian menunjukkan bahwa ketepatan hasil SPKK terhadap DASS-42 sebesar 71,43\% (30 dari 42 item/gejala). Item/gejala yang beririsan secara signifikan antara gangguan kecemasan dan stress sebesar 16,67\%. (7 dari 42), antara depresi dan kecemasan sebesar 9,52\% (4 dari 42). Secara umum SPKK ini mampu mengakomodasi preferensi para pengambil keputusan dalam memberikan bobot pengaruh. Gangguan kecemasan dan gangguan stress memiliki gejala yang sangat mirip sehingga untuk beberapa item/gejala pada DASS-42 ada perbedaan yang cukup signifikan.
\end{abstract}

Kata kunci: kelompok, gangguan, preferensi, depresi, kecemasan, stress

\section{GROUP DECISION SUPPORT SYSTEM MODEL FOR ASSESSMENT OF DEPRESSION, ANXIETY AND STRESS DISORDERS BASED ON DASS-42}

\begin{abstract}
Depression, anxiety and stress are three disorders that are often found in the community. These three disorders have almost identical symptoms. Depression, Anxiety and Stress Scales (DASS) is an psychological instrument that can be used to measure the severity of these disorders. DASS with a total of 42 items known as DASS-42. This instrument distinguishes clearly the symptoms of each disorder. Each disorder has 14 items affect. The three disorders have a number of symptoms that are similar, even a symptom may affect two or three disorders with different levels of influence. In this study, a Group Decision Support System (GDSS) model was developed so that psychologists can collaborate to give preference regarding priority of disorders that would occur if certain items / symptoms were identified by DASS-42. Preferences are given in ordered vectors format. The preferences given by each decision maker aggregated to get a single preference. These preferences will be transformed to the fuzzy preference relation format. Ordered Weighted Averaging (OWA) operator used to aggregation process for all decision maker preference. The OWA operator are used to aggregate into one matrix. The best alternative selected by using Quantifier Guided Dominance Degree (QGDD). The test results show that the accuracy of the GDSS results on DASS-42 is $71.43 \%$ (30 of 42 items / symptoms). Symptoms that overlap significantly between anxiety and stress disorders are 16.67\%. (7 of 42), between depression and anxiety by $9.52 \%$ (4 of 42). The GDSS is able to accommodate the preferences of decision makers in giving influence weight. Anxiety and stress disorder have very similar symptoms so that for some symptoms in the DASS-42 there are significant differences.
\end{abstract}

Keywords: group, disorder, preference, depression, anxiety, stress 


\section{PENDAHULUAN}

Faktor-faktor stress ekonomi seperti kesulitan ekonomi, ancaman finansial dan kesejahteraan finansial terbukti berhubungan positif dengan munculnya gangguan depresi, kecemasan, dan stress (Viseu, et.al, 2018). Menurut data dari WHO terdapat penderita depresi mengalami kenaikan sebesar $18 \%$ sejak tahun 2005 (CNN, 2017). Sementara menurut data dari Perhimpunan Dokter Spesialis Kesehatan Jiwa Indonesia (PDSKJI) melalui Tempo (2017), prevalensi penderita depresi di Indonesia sebesar $3,7 \%$, sekitar 9 juta jiwa dari 250 juta penduduk Indonesia. Dari total penderita depresi tersebut hanya $8 \%$ yang dapat terlayani, sedangkan sisanya sebanyak $92 \%$ tidak mendapatkan pelayanan yang tepat (Sativa, 2017). Depresi bisa menyebabkan percobaab bunuh diri hingga lebih dari 800.000 kasus setiap tahun di seluruh dunia (WHO, 2017). Gangguan depresi dianggap sebagai penyebab utama gangguan emosi dan penurunan kualitas hidup (Denise et al., 2017).

Untuk melihat seberapa besar tingkat gangguan kejiwaan seseorang dapat digunakan beberapa alat ukur. Depression Anxiety Stress Scales (DASS) merupakan salah satu alat ukur yang lazim digunakan. DASS adalah skala asesmen diri sendiri (self-assesment scale) yang digunakan untuk mengukur kondisi emosional negatif seseorang yaitu depresi, kecemasan dan stress (NovoPsych. 2018). Ada 42 butir/item penilaian yang digunakan. Tujuan utama pengukuran dengan DASS adalah untuk menilai tingkat keparahan (severe level) gejala inti depresi, kecemasan dan stress. Dari 42 item tersebut sebanyak 14 item berkaitan dengan gejala depresi, 14 item berkaitan dengan gejala kecemasan dan 14 item berkaitan dengan gejala stress. Dengan pembagian gejala seperti ini satu item hanya dimungkinkan mempengaruhi satu jenis gangguan saja. Padahal kenyataannya sangat memungkinkan satu item merupakan gejala dari beberapa gangguan walaupun dengan prioritas yang berbeda. Untuk memberikan prioritas yang menunjukkan jenis gangguan mana (depresi, kecemasan atau stress) yang dipengaruhi oleh suatu item perlu pertimbangan dari beberapa psikolog. Konsensus dari para psikolog tersebut dapat dijadikan sebagai acuan pembobotan item pada DASS.

Pengambilan keputusan yang mengakomodasi pendapat dari beberapa pengambil keputusan dapat difasilitasi oleh teknologi informasi melalui pengembangan Sistem Pendukung Keputusan Kelompok (SPKK). SPKK merupakan sebuah sistem yang dilengkapi dengan dukungan dalam penyelesaian masalah dan komunikasi dalam suatu grup. SPKK memungkinkan adanya struktur yang jelas dalam proses pengambilan keputusan untuk menghasilkan, mengklarifikasi, mengurangi, mengatur, dan mengevaluasi ide-ide dari anggota kelompok (Hillegersberg \& Koenen, 2014). Sinergi antara manajemen pengetahuan dan sistem pendukung keputusan dapat diimplementasikan pada Group Support System (GSS) (Alyoubi, 2015). GSS merupakan sistem yang dibangun dengan mengakomodasi peran dari beberapa pengambil keputusan dalam memutuskan atau memberikan solusi atas beberapa masalah dalam suatu kelompok. Untuk keperluan tersebut, pada penelitian ini akan dibuat model SPKK yang mampu mengakomodasi hal tersebut. Model SPKK yang dibangun memungkinkan para psikolog untuk berkolarorasi memberikan preferensinya dalam menyelesaikan permasalahan (dalam hal ini adalah penentuan prioritas gangguan)

Kelompok adalah kumpulan individu yang: 1) umumnya bersifat dinamis (jarang sekali terisolasi); 2) memiliki masa lalu dan memiliki harapan yang lebih baik di masa mendatang; 3) menyelesaikan tugas-tugas tertentu dan biasanya tugas-tugas tersebut cukup kompleks; dan 4) bersifat multi fungsi (McGrath, 2014). Menurut Turban (2005), sifat-sifat dari pengambilan keputusan kelompok atau Group Decision Making (GDM) adalah 1) perlu adanya pertemuan; 2) hasil pertemuan tergantung pada pengetahuan dan pendapat dari anggota kelompok; 3) perlu adanya komposisi dan proses pengambilan keputusan; dan 4) perlu adanya penyelesaian jika terjadi perbedaan pendapat. Kelompok umumnya terdiri dari individu yang berasal dari latar belakang berbeda, memiliki beragam pengalaman dan pengetahuan. Perbedaan ini dapat mengakibatkan konflik dalam kelompok yang dapat merugikan kinerja kelompok (Bose, 2015). Pada penelitian ini, kelompok terdiri atas para psikolog yang akan berkolarorasi dalam penyelesaian masalah,

Dalam pengambilan keputusan, para pengambil keputusan dalam suatu kelompok dapat menggunakan format representasi yang berbeda untuk memberikan pendapat atau preferensi mereka pada sekumpulan alternatif, baik dalam bentuk numerik atau teks. Salah satu format representasi terkenal adalah relasi preferensi, yang didasarkan pada perbandingan alternatif berpasangan (Kamis et.al, 2018). Dalam masalah pengambilan keputusan kelompok, diinginkan untuk mendapatkan solusi dengan tingkat kesepakatan tertinggi - konsensus - di antara para peserta. Untuk tujuan ini, perlu memiliki alat yang memfasilitasi penghitungan tingkat konsensus dengan cara yang dapat diandalkan (delMoral et.al, 2017).

\section{DEPRESSION ANXIETY STRESS (DASS)- 42}

Alat ukur yang digunakan pada penelitian ini adalah DASS-42. Pada DASS-42 ada 42 item yang ditanyakan, seperti pada Tabel 1 (NovoPsych. 2018). 
Pada standar DASS-42, pembagian item/gejala yang mempengaruhi gangguan tertentu dapat dilihat pada Tabel 2.

\begin{tabular}{|c|c|}
\hline No & Item/Gejala \\
\hline 1 & Menjadi marah karena hal-hal kecil/sepele \\
\hline 2 & Mulut terasa kering \\
\hline 3 & Tidak dapat melihat hal yang positif dari suatu kejadian \\
\hline 4 & $\begin{array}{l}\text { Merasakan gangguan dalam bernafas (nafas cepat, sulit } \\
\text { bernafas) }\end{array}$ \\
\hline 5 & Merasa tidak kuat lagi untuk melakukan kegiatan \\
\hline 6 & Cenderung bereaksi berlebihan terhadap suatu situasi \\
\hline 7 & Kelemahan pada anggota tubuh \\
\hline 8 & Kesulitan untuk berelaksasi/bersantai \\
\hline 9 & $\begin{array}{l}\text { Cemas berlebihan dalam suatu situasi namun bisa lega } \\
\text { bila situasi/hal itu berakhir }\end{array}$ \\
\hline 10 & Pesimis \\
\hline 11 & Mudah merasa kesal \\
\hline 12 & Merasa banyak menghasilkan energi karena cemas \\
\hline 13 & Merasa sedih dan depresi \\
\hline 14 & Tidak sabaran \\
\hline 15 & Kelelahan \\
\hline 16 & $\begin{array}{l}\text { Kehilangan minat pada banyak hal (misal makan, } \\
\text { ambulasi, sosialiasi) }\end{array}$ \\
\hline 17 & Merasa diri tidak layak \\
\hline 18 & Mudah tersinggung \\
\hline 19 & Berkeringat \\
\hline 20 & Ketakutan tanpa alasan yang jelas \\
\hline 21 & Merasa hidup tidak berharga \\
\hline 22 & Sulit untuk beristirahat \\
\hline 23 & Kesulitan dalam menelan \\
\hline 24 & Tidak dapat menikmati hal-hal yang dilakukan \\
\hline 25 & $\begin{array}{l}\text { Perubahan kegiatan jantung dan denyut nadi tanpa } \\
\text { stimulasi oleh latihan fisik }\end{array}$ \\
\hline 26 & Merasa hilang harapan dan putus asa \\
\hline 27 & Mudah marah \\
\hline 28 & Mudah panik \\
\hline 29 & $\begin{array}{l}\text { Kesulitan untuk tenang setelah sesuatu yang } \\
\text { mengganggu }\end{array}$ \\
\hline 30 & $\begin{array}{l}\text { Takut diri terhambat oleh tugas -tugas yang tidak bisa } \\
\text { dilakukan }\end{array}$ \\
\hline 31 & Sulit untuk antusias pada banyak hal \\
\hline 32 & $\begin{array}{l}\text { Sulit menteloransi gangguan-gangguan terhadap hal-hal } \\
\text { yang dilakukan }\end{array}$ \\
\hline 33 & Berada pada keadaan tegang \\
\hline 34 & Berasa tidak berharga \\
\hline 35 & $\begin{array}{l}\text { Tidak dapat memaklumi hal apapun yang menghalangi } \\
\text { untuk menyelesaikan hal yang sedang dilakukan }\end{array}$ \\
\hline 36 & Ketakutan \\
\hline 37 & Tidak ada harapan untuk masa depan \\
\hline 38 & Merasa hidup tidak berarti \\
\hline 39 & Mudah gelisah \\
\hline 40 & $\begin{array}{l}\text { Khawatir dengan situasi saat diri anda mungkin menjadi } \\
\text { panik dan mempermalukan diri anda sendiri }\end{array}$ \\
\hline 41 & Gemetar \\
\hline 42 & $\begin{array}{l}\text { Sulit untuk meningkatkan inisaitif dalam melakukan } \\
\text { sesuatu }\end{array}$ \\
\hline
\end{tabular}

Tabel 2. Pembagian Item/Gejala terhadap Gangguan

\begin{tabular}{ll} 
Gangguan & \multicolumn{1}{c}{ No Item/Gejala } \\
\hline Depresi & $3,5,10,13,16,17,21,24,26,31,34,37,38,42$ \\
Kecemasan & $2,4,7,9,15,19,20,23,25,28,30,36,40,41$ \\
Stress & $1,6,8,11,12,14,18,22,27,29,32,33,35,39$ \\
\hline
\end{tabular}

Self assesment dilakukan dengan cara mengisikan nilai 0 : tidak terjadi, 1 : jarang terjadi, 2 : kadang terjadi atau 3: sering terjadi pada setiap item. Pada Tabel 2, misalkan item nomor 39 (mudah gelisah), sesuai DASS-42 akan direkomendasikan sebagai gejala gangguan stress, namun demikian mudah gelisah sebenarnya juga menjadi bagian dari gangguan depresi dan kecemasan. Demikian pula misalkan nomor 36 (ketakutan), sesuai DASS-42 akan direkomendasikan sebagai gejala gangguan kecemasan, namun demikian mudah ketakutan sebenarnya juga menjadi bagian dari gangguan depresi dan stress. Sejauh ini belum ada penelitian/literatur terkait ranking prioritas gangguan setiap butir. Prioritas hanya ditentukan sebatas mempengaruhi atau tidak mempengaruhi, tidak menunjukkan ranking pengaruh setiap gangguan.

Skor akhir untuk DASS-42 dihitung berdasarkan total nilai pada setiap gangguan, sehingga maksimal total skor untuk setiap gangguan adalah sebesar $3 \mathrm{x}$ $14=42$. Tingkat keparahan setiap gangguan dapat dilihat pada Tabel 3 (SerenityPrograme, 2017).

Tabel 3. Tingkat Keparahan Gangguan.

\begin{tabular}{lccccc}
\hline \multirow{2}{*}{ Gangguan } & \multicolumn{5}{c}{ Tingkat Keparahan } \\
\cline { 2 - 6 } & Normal & Ringan & Sedang & Berat & $\begin{array}{c}\text { Sangat } \\
\text { Berat }\end{array}$ \\
\hline Depresi & $0-9$ & $10-13$ & $14-20$ & $21-27$ & $28+$ \\
Kecemasan & $0-7$ & $8-9$ & $10-14$ & $15-19$ & $20+$ \\
Stress & $0-14$ & $15-18$ & $19-25$ & $26-33$ & $34+$ \\
\hline
\end{tabular}

\section{METODE PENELITIAN}

Penelitian dilakukan melalui beberapa tahapan seperti terlihat pada Gambar 1.

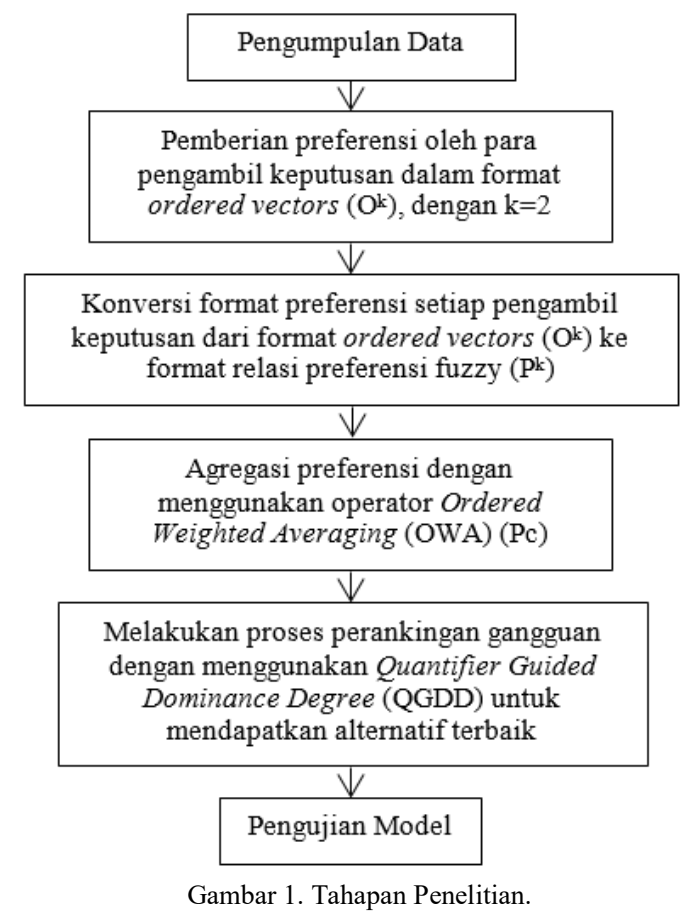

Tahapan penelitian pada Gambar 1 dijelaskan sebagai berikut:

1. Tahap pengumpulan data. Tahap ini dilakukan melalui dua cara, yaitu kajian pustaka, pengumpulan data melalui kuisioner dan Focus Group Discussion (FGD). Observasi dan FGD dilakukan dengan Pusat Konsultasi Keluarga (Puskaga) UII. Pengumpulan data melalui 
kuisioner dilakukan dalam rangka pemberian preferensi psikolog terhadap item-item yang ada pada DASS 42 untuk dicari prioritas gangguan yang relevan (depresi, kecemasan atau stress). Ada dua psikolog yang berperan dalam memberikan pendapat. Pengumpulan data melalui observasi dan FGD dilakukan dalam rang mencari masukan terkait pengembangan aplikasi SPKK yang akan dibuat.

2. Pemberian Preferensi oleh Pengambil Keputusan. Pemberian preferensi dilakukan dengan menggunakan konsep ordered vectors. Proses memberikan pendapat oleh psikolog dilakukan dengan cara memberikan prioritas berupa angka 1, 2, dan 3. Angka 1 menunjukkan prioritas pertama, semakin besar angka, semakin tidak berprioritas. Format lain yang dapat digunakan untuk memberikan preferensi adalah dengan menggunakan matriks perbandingan berpasangan seperti yang digunakan pada metode Analytic Hierarchy Process (AHP). AHP dapat mengurutkan preferensi alternatif berdasarkan perbandingan kriteria (Rahmanita, et.al., 2018). Ordered vector lebih dipilih karena formatnya yang relatif sederhana untuk jumlah alternatif yang tidak terlalu banyak.

3. Transformasi format preferensi ke fuzzy preference relation. Preferensi yang diberikan oleh setiap pengambil keputusan selanjutnya akan digabungkan menjadi satu preferensi tunggal. Sebelum kedua preferensi digabungkan, preferensi yang sudah diberikan dalam format ordered vectors ditransformasikan terlebih dahulu ke format relasi preferensi fuzzy.

4. Agregasi preferensi. Pada penelitian ini digunakan Ordered Weighted Averaging (OWA) untuk melakukan agregasi preferensi.

5. Seleksi alternatif terbaik. Pada penelitian ini akan digunakan Quantifier Guided Dominance Degree (QGDD).

6. Pengujian model. Pengujian model dilakukan dengan dua cara, yaitu: 1) Menguji kesesuaian prioritas utama hasil SPKK dibandingkan dengan DASS-42 yang asli; dan 2) Memberikan nilai maksimal untuk semua item/gejala pada gangguan yang paling dominan menurut DASS42 dan memberikan nilai minimal untuk semua item/gejala pada gangguan lainnya.

\section{HASIL DAN PEMBAHASAN}

\subsection{Pemberian Preferensi oleh Pengambil Keputusan}

Format preferensi ordered vectors adalah: $\mathrm{O}^{\mathrm{k}}=$ $\left(\mathrm{o}^{\mathrm{k}}(1), \mathrm{o}^{\mathrm{k}}(2), \ldots, \mathrm{o}^{\mathrm{k}}(\mathrm{m})\right)$ dengan $\mathrm{o}^{\mathrm{k}}($.$) merupakan$ fungsi kemungkinan pertukaran (permutasi) terhadap anggota-anggota himpunan indeks $\{1,2, \ldots, \mathrm{m}\}$ dan $\mathrm{o}^{\mathrm{k}}$ (i) merepresentasikan ranking yang diberikan oleh pengambil keputusan $e^{k}$ dari alternatif $a_{i}, i=1,2, \ldots, m$ (Kusumadewi et.al, 2006). Ranking disajikan sev=cara terurut mulai dari nilai terbaik hingga terburuk. Pada penelitian ini nilai $\mathrm{k}=2$ (ada dua pengambil keputusan) dan nilai $\mathrm{m}=3$ (ada tiga alternatif gangguan, yaitu depresi, kecemasan dan stress). Preferensi untuk kedua pengambil keputusan dapat dilihat pada Tabel 4. Sebagai contoh pada baris pertama untuk pengambil keputusan pertama $\left(\mathrm{e}^{1}\right), \mathrm{O}^{1}$ $=(3,2,1)$ dan pengambil keputusan kedua $\left(\mathrm{e}^{2}\right), \mathrm{O}^{2}=$ $(3,1,2)$.

\begin{tabular}{|c|c|c|c|c|c|c|}
\hline \multirow[b]{2}{*}{ No } & \multicolumn{3}{|c|}{ Pengambil Keputusan 1} & \multicolumn{3}{|c|}{ Pengambil Keputusan 2} \\
\hline & Depresi & $\begin{array}{l}\text { Kece- } \\
\text { masan }\end{array}$ & Stress & Depresi & $\begin{array}{l}\text { Kece- } \\
\text { masan }\end{array}$ & Stress \\
\hline 1 & 3 & 2 & 1 & 3 & 1 & 2 \\
\hline 2 & 3 & 2 & 1 & 3 & 1 & 2 \\
\hline 3 & 1 & 3 & 2 & 1 & 3 & 2 \\
\hline 4 & 1 & 3 & 2 & 3 & 1 & 2 \\
\hline 5 & 1 & 3 & 2 & 1 & 3 & 2 \\
\hline 6 & 3 & 2 & 1 & 3 & 2 & 1 \\
\hline 7 & 1 & 3 & 2 & 1 & 3 & 2 \\
\hline 8 & 1 & 3 & 2 & 1 & 3 & 2 \\
\hline 9 & 3 & 1 & 2 & 3 & 1 & 2 \\
\hline 10 & 1 & 3 & 2 & 1 & 3 & 2 \\
\hline 11 & 3 & 1 & 2 & 3 & 1 & 2 \\
\hline 12 & 3 & 1 & 2 & 2 & 1 & 3 \\
\hline 13 & 1 & 3 & 2 & 1 & 2 & 2 \\
\hline 14 & 3 & 1 & 2 & 3 & 1 & 2 \\
\hline 15 & 1 & 3 & 2 & 1 & 3 & 2 \\
\hline 16 & 1 & 3 & 2 & 1 & 3 & 2 \\
\hline 17 & 1 & 3 & 2 & 1 & 3 & 2 \\
\hline 18 & 3 & 2 & 1 & 3 & 1 & 2 \\
\hline 19 & 3 & 1 & 2 & 3 & 1 & 2 \\
\hline 20 & 3 & 1 & 2 & 3 & 1 & 2 \\
\hline 21 & 1 & 3 & 2 & 1 & 3 & 2 \\
\hline 22 & 1 & 3 & 2 & 1 & 3 & 2 \\
\hline 23 & 3 & 2 & 1 & 3 & 1 & 2 \\
\hline 24 & 1 & 3 & 2 & 1 & 3 & 2 \\
\hline 25 & 3 & 1 & 2 & 3 & 1 & 2 \\
\hline 26 & 1 & 3 & 2 & 1 & 3 & 2 \\
\hline 27 & 3 & 1 & 2 & 3 & 1 & 2 \\
\hline 28 & 3 & 1 & 2 & 3 & 1 & 2 \\
\hline 29 & 3 & 1 & 2 & 3 & 1 & 2 \\
\hline 30 & 3 & 1 & 2 & 3 & 1 & 2 \\
\hline 31 & 1 & 3 & 2 & 1 & 3 & 2 \\
\hline 32 & 3 & 1 & 2 & 3 & 1 & 2 \\
\hline 33 & 3 & 2 & 1 & 3 & 1 & 2 \\
\hline 34 & 1 & 3 & 2 & 3 & 1 & 2 \\
\hline 35 & 3 & 1 & 2 & 2 & 1 & 3 \\
\hline 36 & 3 & 1 & 2 & 1 & 3 & 2 \\
\hline 37 & 1 & 3 & 2 & 1 & 3 & 2 \\
\hline 38 & 1 & 3 & 2 & 3 & 1 & 2 \\
\hline 39 & 3 & 2 & 1 & 3 & 1 & 2 \\
\hline 40 & 3 & 1 & 2 & 3 & 1 & 2 \\
\hline 41 & 3 & 2 & 1 & 3 & 1 & 2 \\
\hline 42 & 3 & 2 & 1 & 1 & 3 & 2 \\
\hline
\end{tabular}

\subsection{Transformasi Preferensi ke Relasi Preferensi Fuzzy}

Setiap pengambil keputusan memberikan preferensinya dalam bentuk matriks $P=\left\{p_{i j} \mid\right.$ $\mathrm{i}, \mathrm{j}=1,2, . ., \mathrm{m}\}$, dengan $\mathrm{p}_{\mathrm{ij}}$ adalah derajat preferensi alternatif $a_{i}$ terhadap $a_{j}, p_{i j}+p_{j i}=1$. Menurut HerreraViedma (2007), relasi preferensi fuzzy, P, pada himpunan alternatif $X$ adalah himpunan fuzzy dalam bentuk $\mathrm{X} \times \mathrm{X}$, yang dicirikan dengan fungsi keanggotaan seperti terlihat pada Persamaan (1):

$\mu_{\mathrm{P}}: \mathrm{X} \mathbf{x} \mathrm{X} \rightarrow[0,1]$ 
dengan $\mathrm{P}=\left(\mathrm{p}_{\mathrm{ij}}\right)$, dan $\mathrm{p}_{\mathrm{ij}}=\mu_{\mathrm{P}}\left(\mathrm{x}_{\mathrm{i}}, \mathrm{x}_{\mathrm{j}}\right) \quad \forall \mathrm{i}, \mathrm{j}=$ $\{1,2, \ldots, n\}$ adalah derajat preferensi alternatif $\mathrm{x}_{\mathrm{i}}$ terhadap alternatif $\mathrm{x}_{\mathrm{j}}$. Jika $\mathrm{p}_{\mathrm{ij}}=1 / 2$ menunjukkan bahwa antara $\mathrm{x}_{\mathrm{i}}$ dengan $\mathrm{x}_{\mathrm{j}}\left(\mathrm{x}_{\mathrm{i}} \sim \mathrm{x}_{\mathrm{j}}\right)$ tidak ada perbedaan; jika $p_{i j}=1$ menunjukkan bahwa $x_{i}$ muxlak lebih baik daripada $\mathrm{x}_{\mathrm{j}}$; dan jika $\mathrm{p}_{\mathrm{ij}}>1 / 2$ menunjukkan bahwa $\mathrm{x}_{\mathrm{i}}$ lebih baik daripada $\mathrm{x}_{\mathrm{j}}$.

Ma dalam Kusumadewi (2006) mengatakan bahwa transformasi antara alternatif $\mathrm{A}_{\mathrm{i}}$ dan $\mathrm{A}_{\mathrm{j}}$ dari format ordered vectors ke relasi preferensi fuzzy dapat dilakukan dengan menggunakan Persamaan (2):

$\mathrm{p}_{\mathrm{ij}}^{\mathrm{k}}=\frac{1}{2}\left(1+\frac{\mathrm{o}^{\mathrm{k}}(\mathrm{j})}{\mathrm{m}-1}-\frac{\mathrm{o}^{\mathrm{k}}(\mathrm{i})}{\mathrm{m}-1}\right) ; \quad 1 \leq \mathrm{i} \neq \mathrm{j} \leq \mathrm{m}$

dengan $\mathrm{O}_{\mathrm{j}}^{\mathrm{k}}$ adalah posisi ranking alternatif $\mathrm{A}_{\mathrm{j}} \mathrm{di} \mathrm{O}^{\mathrm{k}}$, $\mathrm{j}=1,2, \ldots, \mathrm{m}$.

Sebagai contoh, untuk data pada Tabel 2 baris pertama yaitu "Menjadi marah karena hal-hal sepele" (sesuai Tabel 1), dengan menggunakan Persamaan (2) diperoleh matriks relasi preferensi fuzzy untuk pengambil keputusan pertama, $P^{1}=$ $\left[\begin{array}{ccc}0,5 & 0,25 & 0 \\ 0,75 & 0,5 & 0,25 \\ 1 & 0,75 & 0,5\end{array}\right]$ dan pengambil keputusan kedua, $P^{2}=\left[\begin{array}{ccc}0,5 & 0 & 0,25 \\ 1 & 0,5 & 0,75 \\ 0,75 & 0,25 & 0,5\end{array}\right]$

\subsection{Agregasi Preferensi}

Untuk mendapatkan satu matriks preferensi tunggal perlu dilakukan agregasi preferensi dari kedua pengambil keputusan. Agregasi preferensi dalam format relasi preferensi fuzzy dapat dilakukan dengan berbagai metode, seperti: Ordered Weighted Averaging (OWA), Importance Induced Ordered Weighted Averaging (I-IOWA), Consistency Induced Ordered Weighted Averaging (C-IOWA) atau Importance Induced Ordered Weighted Averaging (P-IOWA) (Kusumadewi, 2006).

OWA merupakan operator agregasi yang bersifat komutatif, kontinyu, monoton dan sangat cocok digunakan pada transformasi linear. Pada dasarnya operator OWA akan bekerja dengan cara mengurutkan argumen-argumen untuk diagregasikan berdasarkan nilai respon yang diberikan. Menurut Chiclana dalam Kusumadewi (2006):

Operator OWA dari suatu fungsi berdimensi $\mathrm{n}$,

$\phi: \mathfrak{R}^{\mathrm{n}} \rightarrow \mathfrak{K}$, yang berhubungan dengan vektor bobot $\mathrm{W}=\left(\mathrm{w}_{1}, \ldots, \mathrm{w}_{\mathrm{n}}\right) ; \quad \mathrm{w}_{\mathrm{i}} \in[0,1]$; $\sum_{\mathrm{i}=1}^{\mathrm{n}} \mathrm{w}_{\mathrm{i}}=1 ;$ dan akan digunakan untuk mengagregasikan urutan nilai $\left\{\mathrm{p}_{1}, \ldots, \mathrm{p}_{\mathrm{n}}\right\}$ :

$$
\phi_{\mathrm{w}}\left(\mathrm{p}_{1}, \ldots, \mathrm{p}_{\mathrm{n}}\right)=\sum_{\mathrm{i}=1}^{\mathrm{n}} \mathrm{w}_{\mathrm{i}} \mathrm{p}_{\sigma(\mathrm{i})}
$$

$$
\begin{aligned}
& \text { menjadi suatu bentuk permutasi } \\
& \sigma:\{1, \ldots, \mathbf{n}\} \rightarrow\{1, \ldots, \mathbf{n}\} \\
& \text { hedemikian } \\
& \mathrm{p}_{\sigma(\mathrm{i})} \geq \mathrm{p}_{\sigma(\mathrm{i}+1)}, \forall \mathrm{i}=1, \ldots(\mathrm{n}-1) ; \mathrm{p}_{\sigma(\mathrm{i})} \text { adalah } \\
& \text { nilai yang paling tinggi dalam himpunan } \\
& \left\{\mathrm{p}_{\left.1, \ldots, \mathrm{p}_{\mathrm{n}}\right\} .}\right.
\end{aligned}
$$

Jika terdapat $\mathrm{n}$ kriteria sebagai himpunan bagian fuzzy dari himpunan alternatif $X$, pada tahap agregasi operator OWA dapat digunakan untuk menunjukkan konsep mayoritas fuzzy dengan menggunakan fuzzy linguistic quantifier. Quantifier (pencacah) digunakan untuk merepresentasikan sejumlah item tertentu yang memenuhi suatu predikat yang diberikan. Pada penelitian ini akan digunakan pencacah bertipe Regular Increasing Monotone (RIM). Ciri RIM adalah adanya hubungan $\mathrm{Q}\left(\mathrm{r}_{1}\right) \geq$ $\mathrm{Q}\left(\mathrm{r}_{2}\right)$ jika $\mathrm{r}_{1}>\mathrm{r}_{2}$ (Liu \& Han, 2008). Menurut Yager (1996) dalam (Liu \& Han, 2008), linguistic quantifier yang paling banyak digunakan pada RIM adalah "all", "most", "many" dan "there exist" dengan menggunakan $\mathrm{Q}(\mathrm{r})=\mathrm{r}^{\alpha}, \alpha \geq 0$. Linguistic quantifer "most" diberikan dengan parameter $\alpha=2$. Untuk mendapatkan bobot OWA, dapat dihitung dengan persamaan sebagai berikut:

$\mathrm{w}_{\mathrm{i}}=\mathrm{Q}\left(\frac{\mathrm{i}}{\mathrm{n}}\right)-\mathrm{Q}\left(\frac{\mathrm{i}-1}{\mathrm{n}}\right) ; \quad \mathrm{i}=1, \ldots, \mathrm{n}$.

Nilai dari persamaan (4) ini akan selalu naik, sehingga apabila dibutuhkan suatu kondisi dimana bobot yang lebih tinggi akan menunjukkan konsistensi yang lebih rendah, maka dapat dilakukan modifikasi dengan cara mengurutkan pengambil keputusan berdasarkan kriteria yang berlawanan atau menggunakan nilai $\alpha<1$, misal $Q(r)=r^{1 / 2}$.

Pada penelitian ini digunakan linguistic quantifer "most" diberikan dengan parameter $\alpha=1 / 2$, sehingga Persamaan (4) menjadi:

$w_{i}=\sqrt{\frac{i}{n}}-\sqrt{\frac{i-1}{n}} ; i=1, \ldots, n$

Sebagai untuk penelian ini dengan menggunakan Persamaan (5) diperoleh:

$w_{1}=\sqrt{\frac{1}{2}}-\sqrt{\frac{0}{2}}=0,71$

$w_{2}=\sqrt{\frac{2}{2}}-\sqrt{\frac{2-1}{2}}=0,29$

Sebelum dilakukan proses agregasi, preferensi kedua pengambil keputusan $\mathrm{P}^{1}$ dan $\mathrm{P}^{2}$ harus diurutkan terlebih dahulu sedemikian hingga $\mathrm{p}_{\sigma(\mathrm{i})} \geq \mathrm{p}_{\sigma(\mathrm{i}+1)}, \forall \mathrm{i}=1, \ldots(\mathrm{n}-1)$, sehingga diperoleh:

$P_{\propto}^{1}=\left[\begin{array}{ccc}0,5 & 0,25 & 0,25 \\ 1 & 0,5 & 0,75 \\ 1 & 0,75 & 0,5\end{array}\right]$ dan $P_{\propto}^{2}=\left[\begin{array}{ccc}0,5 & 0 & 0 \\ 0,75 & 0,5 & 0,25 \\ 0,75 & 0,25 & 0,5\end{array}\right]$

Agregasi matriks preferensi Pc diperoleh dari preferensi kedua pengambil keputusan yang telah 
diurutkan $P_{\propto}^{1}$ dan $P_{\propto}^{2}$ dengan menggunakan Persamaan (3), (6) dan (7) sebagai berikut:

$P c=\left[\begin{array}{ccc}0,5 & 0,177 & 0,177 \\ 0,927 & 0,5 & 0,604 \\ 0,927 & 0,604 & 0,5\end{array}\right]$

\subsection{Seleksi Alternatif Terbaik}

Ada beberapa cara untuk menyeleksi alternatif terbaik dari beberapa alternatif yang ada setelah diperoleh matriks agregasi relasi preferensi fuzzt (Herrera-Viedma, 2007). Pada penelitian ini akan digunakan Quantifier Guided Dominance Degree (QGDD). Pada QGDD pengukuran dominasi suatu alternatif $a_{i}$ terhadap alternatif yang lainnya $a_{j}$ $(j=1, \ldots, m)$ diwujudkan dalam bentuk fuzzy majority sebagai berikut (Huang et.al, 2006):

$Q G D D_{\left(a_{i}\right)}=F_{Q}\left(p_{i j}^{C}, j=1, \ldots, m, i \neq j\right)$

dengan $F_{Q}\left(a_{1, \ldots,} a_{m}\right)=\sum_{i=1}^{m} w_{i} b_{i}$ dan $b_{\mathrm{i}}$ merupakan elemen tertinggi ke-i dari $\left(\mathrm{a}_{1}, \ldots, \mathrm{a}_{\mathrm{m}}\right)$

Pada penelitian ini sebelum dihitung nilai QGDD terlebih dahulu perlu dilakukan pengurutan nilai Pc pada Persamaan (8) di setiap baris dalam rangka untuk mendapatkan nilai $b_{i}$. Hasil pengurutan Persamaan (9) diperoleh Pc' sebagai berikut:

$P c^{\prime}=\left[\begin{array}{ccc}0,5 & 0,177 & 0,177 \\ 0,927 & 0,604 & 0,5 \\ 0,927 & 0,604 & 0,5\end{array}\right]$

Untuk melakukan seleksi alternatif terbaik ini juga digunakan linguistic quantifer "most", sehingga dengan menggunakan Persamaan (5) diperoleh:

$w_{1}=\sqrt{\frac{1}{3}}-\sqrt{\frac{0}{3}}=0,58$

$w_{2}=\sqrt{\frac{2}{3}}-\sqrt{\frac{1}{3}}=0,24$

$w_{3}=\sqrt{\frac{3}{3}}-\sqrt{\frac{2}{3}}=0,18$

QGDD dihitung dengan menggunakan persamaan (9), (10), (11), (12) dan (13) diperoleh hasil sebagai berikut:

$$
\begin{aligned}
\text { QGDD }_{1} & =(0,58) *(0,5)+(0,24)(0,177)+(0,18) *(0,177) \\
& =0,364 \\
\text { QGDD }_{2} & =(0,58) *(0,927)+(0,24)(0,604)+(0,18) *(0,5) \\
& =0,772 \\
\text { QGDD }_{3} & =(0,58) *(0,927)+(0,24)(0,604)+(0,18) *(0,5) \\
& =0,772
\end{aligned}
$$

Hasil ini menunjukkan bahwa gejala "menjadi marah karena hal-hal kecil/sepele" mempengaruhi gangguan depresi sebesar 0,364; mempengaruhi kecemasan sebesar 0,772 dan mempengaruhi stress sebesar 0,772 pula.
Selanjutnya hasil ini dilakukan normalisasi agar total nilai ketiganya sama dengan 1. Persamaan (14) digunakan untuk melakukan normalisasi (V).

$V_{i}=\frac{Q G D D_{i}}{\sum_{j=1}^{n} Q G D D_{j}}$

Dengan menggunakan Persamaan (14), (15), (16), dan (17), hasil normasilasi untuk ketiga hasil di atas adalah sebagai berikut:

$V_{1}=\frac{0,363}{0,363+0,771+0,771}=0,191$

$V_{2}=\frac{0,771}{0,363+0,771+0,771}=0,405$

$V_{3}=\frac{0,771}{0,363+0,771+0,771}=0,405$

Hasil Persamaan (18), (19) dan (20) ini merupakan

\begin{tabular}{|c|c|c|c|c|c|c|}
\hline \multirow[b]{2}{*}{ No } & \multicolumn{3}{|c|}{ Hasil } & \multicolumn{3}{|c|}{ Normalisasi } \\
\hline & Depresi & $\begin{array}{l}\text { Kece- } \\
\text { masan }\end{array}$ & Stress & Depresi & $\begin{array}{l}\text { Kece- } \\
\text { masan }\end{array}$ & Stress \\
\hline 1 & 0,363 & 0,771 & 0,771 & 0,191 & 0,405 & 0,405 \\
\hline 2 & 0,363 & 0,771 & 0,771 & 0,191 & 0,405 & 0,405 \\
\hline 3 & 0,848 & 0,348 & 0,598 & 0,473 & 0,194 & 0,333 \\
\hline 4 & 0,644 & 0,644 & 0,585 & 0,344 & 0,344 & 0,312 \\
\hline 5 & 0,848 & 0,348 & 0,598 & 0,473 & 0,194 & 0,333 \\
\hline 6 & 0,348 & 0,598 & 0,848 & 0,194 & 0,333 & 0,473 \\
\hline 7 & 0,848 & 0,348 & 0,598 & 0,473 & 0,194 & 0,333 \\
\hline 8 & 0,848 & 0,348 & 0,598 & 0,473 & 0,194 & 0,333 \\
\hline 9 & 0,348 & 0,848 & 0,598 & 0,194 & 0,473 & 0,333 \\
\hline 10 & 0,848 & 0,348 & 0,598 & 0,473 & 0,194 & 0,333 \\
\hline 11 & 0,348 & 0,848 & 0,598 & 0,194 & 0,473 & 0,333 \\
\hline 12 & 0,500 & 0,848 & 0,500 & 0,271 & 0,459 & 0,271 \\
\hline 13 & 0,806 & 0,423 & 0,556 & 0,452 & 0,237 & 0,311 \\
\hline 14 & 0,348 & 0,848 & 0,598 & 0,194 & 0,473 & 0,333 \\
\hline 15 & 0,848 & 0,348 & 0,598 & 0,473 & 0,194 & 0,333 \\
\hline 16 & 0,848 & 0,348 & 0,598 & 0,473 & 0,194 & 0,333 \\
\hline 17 & 0,848 & 0,348 & 0,598 & 0,473 & 0,194 & 0,333 \\
\hline 18 & 0,363 & 0,771 & 0,771 & 0,191 & 0,405 & 0,405 \\
\hline 19 & 0,348 & 0,848 & 0,598 & 0,194 & 0,473 & 0,333 \\
\hline 20 & 0,348 & 0,848 & 0,598 & 0,194 & 0,473 & 0,333 \\
\hline 21 & 0,848 & 0,348 & 0,598 & 0,473 & 0,194 & 0,333 \\
\hline 22 & 0,848 & 0,348 & 0,598 & 0,473 & 0,194 & 0,333 \\
\hline 23 & 0,363 & 0,771 & 0,771 & 0,191 & 0,405 & 0,405 \\
\hline 24 & 0,848 & 0,348 & 0,598 & 0,473 & 0,194 & 0,333 \\
\hline 25 & 0,348 & 0,848 & 0,598 & 0,194 & 0,473 & 0,333 \\
\hline 26 & 0,848 & 0,348 & 0,598 & 0,473 & 0,194 & 0,333 \\
\hline 27 & 0,348 & 0,848 & 0,598 & 0,194 & 0,473 & 0,333 \\
\hline 28 & 0,348 & 0,848 & 0,598 & 0,194 & 0,473 & 0,333 \\
\hline 29 & 0,348 & 0,848 & 0,598 & 0,194 & 0,473 & 0,333 \\
\hline 30 & 0,348 & 0,848 & 0,598 & 0,194 & 0,473 & 0,333 \\
\hline 31 & 0,848 & 0,348 & 0,598 & 0,473 & 0,194 & 0,333 \\
\hline 32 & 0,348 & 0,848 & 0,598 & 0,194 & 0,473 & 0,333 \\
\hline 33 & 0,363 & 0,771 & 0,771 & 0,191 & 0,405 & 0,405 \\
\hline 34 & 0,644 & 0,644 & 0,585 & 0,344 & 0,344 & 0,312 \\
\hline 35 & 0,500 & 0,848 & 0,500 & 0,271 & 0,459 & 0,271 \\
\hline 36 & 0,644 & 0,644 & 0,585 & 0,344 & 0,344 & 0,312 \\
\hline 37 & 0,848 & 0,348 & 0,598 & 0,473 & 0,194 & 0,333 \\
\hline 38 & 0,644 & 0,644 & 0,585 & 0,344 & 0,344 & 0,312 \\
\hline 39 & 0,363 & 0,771 & 0,771 & 0,191 & 0,405 & 0,405 \\
\hline 40 & 0,348 & 0,848 & 0,598 & 0,194 & 0,473 & 0,333 \\
\hline 41 & 0,363 & 0,771 & 0,771 & 0,191 & 0,405 & 0,405 \\
\hline 42 & 0,669 & 0,472 & 0,722 & 0,359 & 0,253 & 0,387 \\
\hline
\end{tabular}
hasil prioritas akhir.

Dengan menggunakan cara yang sama, dapat dihitung pengaruh item/gejala terhadap tiga gangguan yang ada diperlihatkan pada Tabel 5 .

Tabel 5. Pengaruh Item/Gejala Terhadap Gangguan 


\subsection{Pengujian}

Seperti telah dijelaskan pada bagian Metode Penelitian, pengujian model ini dilakukan dengan dua tipe, yaitu: 1) Menguji kesesuaian prioritas utama hasil SPKK dibandingkan dengan DASS-42 yang asli; dan 2) Memberikan nilai "sering terjadi (3)" untuk semua item/gejala pada gangguan yang paling dominan menurut DASS-42 dan memberikan nilai "tidak terjadi (0)" untuk semua item/gejala pada gangguan lainnya. Hasil dari pengujian tipe-1 dapat dilihat pada Tabel 6 dan hasil dari pengujian tipe-2 dapat dilihat pada Tabel 9.

\begin{tabular}{|c|c|c|}
\hline \multirow[t]{2}{*}{ No } & \multicolumn{2}{|c|}{$\begin{array}{c}\text { Prioritas Utama } \\
\text { (D: depresi, A: kecemasan, S: stress) }\end{array}$} \\
\hline & DASS-42 & SPKK \\
\hline 1 & $\mathrm{~S}$ & $\mathrm{~A}, \mathrm{~S}$ \\
\hline 2 & A & $\mathrm{A}, \mathrm{S}$ \\
\hline 3 & $\mathrm{D}$ & $\mathrm{D}$ \\
\hline 4 & A & $\mathrm{D}, \mathrm{A}$ \\
\hline 5 & D & $\mathrm{D}$ \\
\hline 6 & $\mathrm{~S}$ & $\mathrm{~S}$ \\
\hline 7 & A & D \\
\hline 8 & $\mathrm{~S}$ & D \\
\hline 9 & A & A \\
\hline 10 & D & D \\
\hline 11 & $\mathrm{~S}$ & A \\
\hline 12 & $\mathrm{~S}$ & A \\
\hline 13 & D & D \\
\hline 14 & $\mathrm{~S}$ & A \\
\hline 15 & A & D \\
\hline 16 & D & D \\
\hline 17 & $\mathrm{D}$ & $\mathrm{D}$ \\
\hline 18 & $\mathrm{~S}$ & $\mathrm{~A}, \mathrm{~S}$ \\
\hline 19 & A & A \\
\hline 20 & A & A \\
\hline 21 & D & $\mathrm{D}$ \\
\hline 22 & $\mathrm{~S}$ & D \\
\hline 23 & A & $\mathrm{A}, \mathrm{S}$ \\
\hline 24 & D & D \\
\hline 25 & A & A \\
\hline 26 & D & $\mathrm{D}$ \\
\hline 27 & $\mathrm{~S}$ & A \\
\hline 28 & A & A \\
\hline 29 & $\mathrm{~S}$ & A \\
\hline 30 & A & A \\
\hline 31 & D & $\mathrm{D}$ \\
\hline 32 & $\mathrm{~S}$ & A \\
\hline 33 & $\mathrm{~S}$ & $\mathrm{~A}, \mathrm{~S}$ \\
\hline 34 & $\mathrm{D}$ & $\mathrm{D}, \mathrm{A}$ \\
\hline 35 & $\mathrm{~S}$ & A \\
\hline 36 & A & $\mathrm{D}, \mathrm{A}$ \\
\hline 37 & D & $\mathrm{D}$ \\
\hline 38 & $\mathrm{D}$ & $\mathrm{D}, \mathrm{A}$ \\
\hline 39 & $\mathrm{~S}$ & $\mathrm{~A}, \mathrm{~S}$ \\
\hline 40 & A & A \\
\hline 41 & A & $\mathrm{A}, \mathrm{S}$ \\
\hline 42 & $\mathrm{D}$ & $\mathrm{S}$ \\
\hline
\end{tabular}

Pengertian prioritas utama pada Tabel 6 adalah gangguan yang memiliki nilai $\mathrm{V}$ terbesar. Dimungkinkan ada prioritas utama yang berisi dua gangguan. Hal ini disebabkan oleh nilai $\mathrm{V}$ terbesar yang sama, misal pada baris pertama kecemasan dan stress memiliki nilai yang sama.

Rekap hasil pengujian tipe-1 dapat dilihat pada
Tabel 7. Ada 13 gangguan depresi sesuai DASS-42 yang juga teridentifikasi gangguan depresi pada SPKK $(93 \%)$, namun ada satu gangguan yang teridentifikasi sebagai stress (7\%). Kondisi kurang baik ada pada gangguan stress. Hanya ada 5 gangguan stress sesuai DASS-42 yang juga teridentifikasi gangguan stress pada SPKK (36\%), 2 teridentifikasi gangguan depresi $(14 \%)$, dan 7 teridentifikasi gangguan kecemasan $(50 \%)$. Secara umum ketepatan hasil pengujian SPKK terhadap DASS-42 adalah sebesar 71,43\% (30 dari 42 item/gejala)

Tabel 7. Rangkuman Hasil Pengujian Tipe-1.

\begin{tabular}{lccc}
\hline Gangguan & Depresi & Kecemasan & Stress \\
\hline Depresi & 13 & 0 & 1 \\
Kecemasan & 2 & 12 & 0 \\
Stress & 2 & 7 & 5 \\
\hline
\end{tabular}

Tabel 8. Gangguan yang Memiliki Prioritas Sama

\begin{tabular}{lccc}
\hline Gangguan & Depresi & Kecemasan & Stress \\
\hline Depresi & - & 4 & 0 \\
Kecemasan & & - & 7 \\
Stress & & & - \\
\hline
\end{tabular}

Gangguan yang memiliki prioritas utama lebih dari satu tercatat ada sebanyak $11(26 \%)$ item/gejala, yang terdiri-dari 7 item dengan gangguan kecemasan \& stress dan 4 item dengan gangguan depresi \& kecemasan (Tabel 8).

\begin{tabular}{cccc}
\multicolumn{4}{c}{ Tabel 9. Hasil Pengujian Preferensi Utama } \\
\hline Kondisi & Depresi & Kecemasan & Stress \\
\hline Kondisi-1 & $\mathbf{1 8 , 6 7 4}$ & 9,357 & 13,969 \\
Kondisi-2 & 10,691 & $\mathbf{1 6 , 7 9 4}$ & 14,515 \\
Kondisi-3 & 10,241 & $\mathbf{1 6 , 8 6 2}$ & 14,897 \\
\hline
\end{tabular}

Tabel 9 menunjukkan hasil pengujian tipe-2. Pengujian dilakukan dengan cara memberikan nilai 3 untuk semua item/gejala pada gangguan yang paling dominan menurut DASS-42 dan memberikan nilai 0 untuk item/gejala lainnya. Kondisi-1 merupakan kondisi dengan gangguan depresi menurut DASS-42 (daftar item/gejala dapat dilihat pada Tabel 2 baris pertama). Kondisi-2 merupakan kondisi dengan gangguan kecemasan menurut DASS-42 (daftar item/gejala dapat dilihat pada Tabel 2 baris kedua). Kondisi-3 merupakan kondisi dengan gangguan stress menurut DASS-42 (daftar item/gejala dapat dilihat pada Tabel 2 baris ketiga). Pada satu kondisi, total nilai preferensi yang diberikan adalah 42 . Pada kondisi-1 preferensi terbesar ada pada gangguan depresi, kondisi-2 dan kondisi-3 preferensi terbesar ada pada gangguan kecemasan.

\subsection{Pembahasan}

Hasil pengujian menunjukkan bahwa gangguan stress dan gangguan kecemasan memiliki irisan yang sangat tinggi. Pada Tabel 8, ada tujuh item/gejala yang memiliki prioritas tinggi pada kecemasan dan stress. Hal ini juga sejalan dengan hasil yang diperlihatkan pada Tabel 7 dimana ada tujuh gangguan yang memiliki prioritas tinggi pada 
gangguan kecemasan, namun pada DASS-42 merupakan gangguan stress. Tujuh yang teridentifikasi gangguan kecemasan tersebut terletak pada item/gejala ke-11, 12, 14, 27, 29, 32 dan 35. Apabila dilihat pada Tabel 4, untuk ketujuh item/gejala tersebut, kedua pengambil keputusan memberikan prioritas pertama pada gangguan kecemasan, sedangkan DASS-42 merekomendasikan item/gejala tersebut lebih berpengaruh pada gangguan stress. Tentu saja hal ini akan menghasilkan keputusan kecemasan sebagai gangguan dengan nilai prioritas gabungan terbesar untuk ketujuh item. Pemberian preferensi yang sangat tergantung pada pengetahuan para pengambil $\mathrm{s}$ menjadi penentu utama dari hasil yang diperoleh.

Secara definitif, stress terjadi atas kejadian yang sedang dialami, sedangkan kecemasan terjadi atas kejadian yang belum dialami. Umumnya kecemasan merupakan reaksi tubuh dalam menghadapi stress. Stress, kecemasan dan ketajutan memang memiliki konsep yang saling tumpang tindih (Chen, 2017). Stress dan kecemasan memang memiliki gejalagejala yang mirip. Perbedaannya terletak pada penyebabnya. Stress disebabkan oleh kondisi yang menekan sedangkan kecemasan disebabkan oleh kekhawatiran akan kejadian yang belum terjadi. Konsekuensi dari stress adalah munculnya gangguan kecemasan, takut, dan depresi (Fink, 2016).

\section{KESIMPULAN DAN SARAN}

\subsection{Kesimpulan}

Dari hasil penelitian yang telah dilakukan, dapat disimpulkan sebagai berikut :

1. Model Sistem Pendukung Keputusan Kelompok (SPKK) sangat relevan diimplementasikan pada kasus pemberian prioritas gangguan pada DASS42. Hal ini disebabkan oleh kemungkinan adanya irisan gejala dari tiga gangguan yaitu depresi, kecemasan dan stress.

2. Penggunaan ordered vector sangat relevan untuk pemberian prioritas pada kasus ini. Hal ini disebabkan oleh jumlah alternatif yang tidak banyak (tiga alternatif yaitu depresi, kecemasan dan stress).

3. Penggunaan operator OWA sangat relevan untuk kasus ini. Hal ini disebabkan oleh sifat pengambil keputusan yang homogen. Keduanya merupakan psikolog dengan bobot kepentingan yang sama.

4. Penggunaan operator QGDD sangat relevan untuk kasus ini. Hal ini disebabkan oleh alternatif yang dipilih adalah alternatif yang paling dominan (paling berprioritas).

5. Hasil pengujian menunjukkan bahwa model SPKK yang diusulkan mampu mengakomodasi pendapat para pengambil keputusan dalam memberikan bobot pengaruh. Gangguan kecemasan dan gangguan stress memiliki gejala yang sangat mirip sehingga untuk beberapa item.gejala pada DASS-42 ada perbedaan yang cukup signifikan.

\subsection{Saran}

Beberapa saran yang dapat diberikan untuk digunakan sebagai bahan perbaikan pada penelitian selanjutnya:

1. Pada penelitian ini psikolog yang bergabung memiliki tingkat pengaruh yang sama (memiliki kepakaran yang sama). Model ini dapat dikembangkan dengan mengakomodasi pengambil keputusan dengan pengaruh yang berbeda. Metode IOWA dapat dipertimbangkan sebagai operator agregasi preferensi pengambil keputusan.

2. Perlu dipertimbangkan untuk mengaplikasikan model ini pada DASS-21. Jumlah item/gejala pada alat ujur ini lebih sedikit (21 item), selanjutnya hasil yang diperoleh dapat dibandingkan dengan hasil penelitian ini.

\section{UCAPAN TERIMAKASIH}

Penelitian ini mendapatkan dukungan pendanaan penuh dari Kemenristekdikti melalui Hibah Penelitian Terapan Unggulan Perguruan Tinggi 2018

\section{DAFTAR PUSTAKA}

ALYOUBI, B.A., 2015. Decision Support System and Knowledge-based Strategic Management. Procedia Computer Science, [online] 65 (2015), pp. 278, 284. Tersedia pada:

$<$ https://www.sciencedirect.com/science/art icle/pii/S1877050915029099>

BOSE, U., 2015. Design and Evaluation of A Group Support System Supported Process to Resolve Cognitive Conflicts. Computers in Human Behavior, [online] 49 (2015), pp. 303, 312. Tersedia pada: $<$ https://www.sciencedirect.com/science/art icle/pii/S0747563215002009>

CHEN, C.V., dan GEORGE, S.A., 2017. Hormones, Brain and Behavior. Third edition. Groningen: Elsenier. Volume 4, pp. 251, 274.

CHICLANA, F., HERRERA-VIEDMA, E., HERRERA, F., dan ALONSO, S., 2007. Some Induced Ordered Weighted Averaging Operators and Their Use for Solving Group Decision Making Problems based on Fuzzy Preference Relations. European Journal of Operational Research, [online] 182 (1), pp. 383, 399. Tersedia pada: $<$ https://www.sciencedirect.com/science/art icle/abs/pii/S0377221706008095> 
CNN, 2017. WHO Umumkan Tingkat Depresi Dunia Naik 18 persen. [online] Tersedia pada: CNN Indonesia $<$ https://www.cnnindonesia.com/gayahidup/20170331090149-255-203950/whoumumkan-tingkat-depresi-dunia-naik-18persen $>$. Diakses pada tanggal 24 Agustus 2018.

delMORAL, M.J., CHICLANAB, F., GARCIAC, J.M.T., dan VIEDMA, E.H., 2017. An Alternative Calculation of The Consensus Degree in Group Decision Making Problems. Procedia Computer Science, [online] 122 (2017), pp. 735, 742. Tersedia pada

$<$ https://www.sciencedirect.com/science/art icle/pii/S1877050917326790>

DENISE, M.A., LUIZ, A.N-M., ALBA, L.B.L.B., JULIANA, L.L., 2017. Predictive Factors of Anxiety and Depression in Patients with Acute Coronary Syndrome. Psychiatric Nursing, [online] 31 (2017), pp. 549, 552. Tersedia pada $<$ https://www.sciencedirect.com/science/art $\mathrm{icle/pii/S0883941717300602>}$

FINK, G., ed. 1., 2016. Stress, Definitions, Mechanisms, and Effects Outlined: Lessons from Anxiety. Dalam Fink, G., 2016. Stress: Concepts, Cognition, Emotion, and Behavior (Handbook of Stress Series). Elsevier. Tersedia pada: $<$ https://www.elsevier.com/books/stressconcepts-cognition-emotion-andbehavior/fink/978-0-12-800951-2>. Diakses pada tanggal 20 April 2018.

HERRERA, F., MARTINEZ, L., dan SANCHEZ, P.J., 2004. Managing non-homogenous Information in Group Decision Making, Europian Journal of Operation Research, [online] 166, pp. 115, 132, Tersedia pada: $<$ http://www.sci2s.ugr.es/publications/fiche ros/EJOR-Herrera-Martinez-Sanchez2004.pdf $>$

HERRERA-VIEDMA, E., CHICLANA, F., HERRERA, F., dan ALONSO, S., 2007. A Group Decision Making Model with Incomplete Fuzzy Preference Relations Based on Additive Consistency. CYBERNETICS, [online] 37 (1), pp. 176, $189 . \quad$ Tersedia pada $<$ https://ieeexplore.ieee.org/document/4067 $078 />$

HILLEGERSBERG, J.V., dan KOENEN, S. 2014. Adoption of web-based Group Decision Support Systems: Conditions for Growth. Procedia Technology, [online] 16 (2014) pp. 675, 683. Tersedia pada
$<$ https://www.sciencedirect.com/science/art icle/pii/S2212017314002436>

HUANG, C-L., LO, C-C., CHAO, K-M,. dan YOUNAS, M., 2006. Reaching Consensus: A Moderated Fuzzy web Services Discovery Method. Information and Software Technology, [online] 48 (6), pp. 410, 423. Tersedia pada: $<$ https://www.sciencedirect.com/science/art icle/abs/pii/S0950584905001977>

KAMIS, N.H., CHICLANA, F., dan LEVESLEYA, J., 2018. Preference Similarity Network Structural Equivalence Clustering based Consensus Group Decision Making Model. Applied Soft Computing, [online] 67 (2018), pp. 706, 720. Tersedia pada: $<$ https://www.sciencedirect.com/science/art icle/pii/S1568494617306853>

KUSUMADEWI, S., HARTATI, S., WARDOYO, R., dan HARJOKO, A., 2006. Fuzzy MultiAttribute Decision Making (FMADM). Yogyakarta: Graha Ilmu.

LIU, X., dan HAN, S., 2008. Orness and Parameterized RIM Quantifier Aggregation with OWA Operators: A Summary. International Journal of Approximate Reasoning, [online] 48 (1), pp. 77, 97. Tersedia pada: $<$ https://www.sciencedirect.com/science/art icle/pii/S0888613X07000709>

NOVOPSYCH, 2018. Depression Anxiety Stress Scales - Long Form (DASS-42). [online] Tersedia pada: NovoPsych: Software for Administering Outcome Questionnaires to Clients for Psychologists: $<$ https://novopsych.com/assessments/depres sion-anxiety-stress-scales-long-form-dass42/>. Diakses pada tanggal 15 Juli 2018.

PERMENSOS, 2010. Peraturan Menteri Sosial Republik Indonesia nomor 84/HUK/2010 tentang Lembaga Konsultasi Kesejahteraan Keluarga. Jakarta.

RAHMANITA, E., PRASTITI, N., dan JAZZARI, I., 2018. Penggunaan Metode AHP dan FAHP dalam Pengukuran Kualitas Keamanan Website E-Commerce. Jurnal Teknologi Informasi dan Ilmu Komputer, [online] 5 (3), pp. 371, 380. Tersedia pada: $<$ http://jtiik.ub.ac.id/index.php/jtiik/article/v iew/816/pdf $>$

SATIVA, R.L., 2017. Waduh! Baru 8 Persen Pasien Depresi di Indonesia yang Tertangani. [online] Tersedia pada: Detik Health $<$ https://health.detik.com/beritadetikhealth/d-3497368/waduh-baru-8persen-pasien-depresi-di-indonesia-yang- 
tertangani>. Diakses pada tanggal 24 Agustus 2018.

SERENITYPROGRAME, 2018. Depressin, Anxiety and Stress Scales (DASS-42). [online] Tersedia pada: Serenity ProgrameCBT@Home

$<$ http://serene.me.uk/tests/dass-42.pdf $>$. Diakses pada tanggal 15 April 2018.

TEMPO, 2017. 9 Juta Orang di Indonesia Mengalami Depresi. [online] Tersedia pada: TEMPO.CO

$<$ https://gaya.tempo.co/read/877228/9-jutaorang-di-indonesia-mengalami-

depresi/full\&view $=$ ok $>$. Diakses pada tanggal 24 Agustus 2018.

TURBAN, E., ARONSON, J.E., LIANG, T-P., 2005. Decision Support Systems and Intelligent Systems. International Edition, ed. 7. New Jersey: Pearson Prentice-Hall Education International

VISEU, J., LEALA, R., DEJESUSA, S.N., PINTOA, P., PECHORROA, P., dan GREENGLASSB, E., 2018. Relationship Between Economic Stress Factors and Stress, Anxiety, and Depression: Moderating Role Of Social Support. Psychiatry Research, [online] 268 (2018), pp. 102, 107. Tersedia pada: $<$ https://www.sciencedirect.com/science/art icle/pii/S0165178117319339>

WHO, 2017. Mental Health. Suicide Data. [online] Tersedia pada: World Health Organization < http://www.who.int/mental_health/preventi on/suicide/suicideprevent/en/>. Diakses pada tanggal 13 Agustus 2018. 